\title{
Empowering Women Entrepreneurs Through Microcredit: Assessing the Role of Sarhad Rural Support Program in Pakistan
}

\author{
Muhammad Ammad Khan ${ }^{1}$, Nazish KanwaP, \\ Peer Ghulam Nabi ${ }^{3}$, Ashfaq Ahmad Shah ${ }^{4}$
}

\begin{abstract}
Microcredit has been recognized as an effective tool to foster entrepreneurship among the rural women. Traditionally, women entrepreneurs in Pakistan are handicapped in the matter of organizing and running their businesses due to absence of capital and fear of failure. With the efforts of state-owned and private microcredit instructions, many Pakistani women are now establishing new businesses with ideas to start micro and small enterprises. This paper intends to examine the role of Sarhad Rural Support Program (SRSP) in empowering women entrepreneurs through microcredit in Khyber Pakhtunkhwa province of Pakistan. The study was undertaken in six villages from three selected districts to examine the effect of microcredit on social and economic empowerment of the rural women entrepreneurs. The field data was collected by applying multistage sampling techniques from the sample size of 300 women entrepreneurs. However, social and economic empowerment index was developed for the assessment of socioeconomic empowerment of the women entrepreneurs. The study found significant improvement in the social and economic status of the women entrepreneurs and concludes that the overall effect of SRSP'S microcredit was positive in empowering women entrepreneurs and promoting entrepreneurship in the study area. However, to effectively address the gender-related constraints and cultural sensitivity that limit equitable access of women entrepreneurs to the local markets, support services are required by the SRSP to create linkages between the women entrepreneurs and local markets.

Keywords: microcredit, women entrepreneurs, social and economic empowerment, Khyber Pakhtunkhwa province, Pakistan.

1 Muhammad Ammad Khan, PhD., Department of Development Studies, College of Humanities and Development, China Agricultural University, 17 Qinghua E Rd, Haidian, Beijing, China. E-mail: ammad_khan84@hotmail.com.

2 Nazish Kanwal, Department of Agricultural Economics and Management, College of Economics and Management, China Agricultural University, 17 Qinghua E Rd, Haidian, Beijing, China. E-mail: nazish_kanwal1986@yahoo.com.

3 Peer Ghulam Nabi, Center for Research and Development Policy, Jammu and Kashmir, India. E-mail: suhailkopor@ gmail.com.

4 Ashfaq Ahmad Shah, PhD., Department of Development Studies, College of Humanities and Development, China Agricultural University, 17 Qinghua E Rd, Haidian, Beijing, China. E-mail: ahmad.ashfaq1986@gmail.com.
\end{abstract}




\section{INTRODUCTION}

The past three decades have been witness to intense struggles and several developments which have brought the issue of women's empowerment, rights and entitlements to the forefront. Especially in the case of rural women, fostering entrepreneurship is widely perceived to be a successful rural development strategy for women empowerment leading to positive change. Microfinance institutions, in this regard, have been playing a significant role in promoting women entrepreneurship in developing countries. These institutions enable poor women to develop their micro and small enterprises which generate income and help them to enjoy an improved standard of living (Mosley, 2001). Many scholars including Claassens, (1993), Kabeer, (1999), Farr-Wharton and Brunetto (2009), Singh and Manisha (2013) have discussed women entrepreneurship in different contexts. Here we draw from Anwar and Amber (2012) who described women entrepreneurs as those who use their knowledge and resources to develop or create new business opportunities - whether this be informally in a home environment without formally registering their business or formally via business registration, hiring office premises, etc. - and who are actively involved in managing their businesses, are responsible in some way for the day-to-day running of the business, and have been in operation for longer than a year.

Empowerment through entrepreneurship leads to self-fulfillment and makes women aware of their status, existence, rights and their position in the society. A series of work, for example Dzisi (2008), Roomi, Harrison and Beaumont-Kerridge (2009), Jamali (2009), Mordi, Simpson, Singh and Okafor (2010), and Itani, Sidani and Baalbaki (2011), explore that socioeconomic factors such as family support, cultural norms of society, lack of skills, selfconfidence, material possession, investment, income and savings etc. discourage women to get into entrepreneurial activities. However, Mishra and Kiran (2014) elucidate that in the modern era, women are becoming socially and economically empowered through business ownership. In social context; women have the power to take decisions, remain autonomous, be self-confident and manage their household independently, through which they can interact within the society (Lemire, Pearson \& Campbell, 2001; Mayoux, 2005); while economic context is their economic stability - they are competent to participate in the economy and make better decisions for their economic position (Golla, Malhotra, Nanda \& Mehra, 2011).

Microcredit encourages women's participation, hypothesizes their sustainability, decreases poverty and enhances socioeconomic development (Mayoux, 2005). Thus microcredit schemes are designed for those who belong to the weak social and economic community, and who are unable to meet their financial needs of business. For instance, the Grameen Model 
(Yunus, 1989) which made microcredit a tool for poverty alleviation at a global level, specifically for rural women, and included for the first time a community approach to poverty reduction and challenged serious obstacles to borrowing, such as collateral, male guarantor or co-signer for female clients, and repayment modalities. A further development took place in this model through some experiences in Latin America, such as that of Americans for Community Co-operation in Other Nations (ACCION), which introduced a business approach to microcredit, through cost-recovery and management as well as individual lending within the group (Berenbach \& Guzman, 1999). Therefore, microcredit evolved further into a development and poverty reduction mechanism based broadly on the Grameen model and other local experiences.

Since the establishment of the Grameen Bank as a microcredit delivery model, many programs have rushed to replicate its relative success and in doing so, a lot of attention has been given to women microcredit borrowers. Women are specifically targeted through microcredit programs because they make up the majority of the poorest of the poor in rural areas and are key actors in the social and economic welfare of the family. During the 1990s, microcredit was seen as successful amongst women clients because of their high repayment rates and savings capacities compared to men. Furthermore, at the same time many Non-Governmental Organization (NGOs) and Donor Agencies (DAs) were dictated by gender policies which specifically called for increased microcredit outreach to women, and these microcredit programs did not limit their desired impact on poverty reduction only, but extended it to achieve women's empowerment (Khandker, 1998; Kabeer, 1999).

\section{Background}

According to a recent assessment by the World Bank, Pakistan has one of the most progressive environments for micro-financing in the world but access to credit by women entrepreneurs is the lowest in the region which is reported at less than 25\% (Mehnaz, 2013). While women represent around $48 \%$ of Pakistan's total population (World Population Prospects, 2015), women's employment participation is however only $19-20 \%$. As per the Labor Force Survey of Pakistan in 2005-06, the contribution of women's labor in agriculture is around $13.4 \%$ and only $6 \%$ are engaged in the non-agriculture sector (PES, 2013-14). The role of Pakistani women is still restricted to household chores. These restrictions often seem to elevate a man's status and importance in society while degrading a woman's status, particularly in the rural areas. Women's lives are neglected or ignored by society's attitudes and treatment towards them. Generally, in rural areas, spouses work together 
to run the household to fulfill their basic needs due to low earnings and high expenditures (IFAD, 2014), and women are considered to be a symbol of continuous struggle. These women are among the millions of laborers who work hard to acquire the basic necessities of life by contributing to the farming, livestock maintenance and post-harvest activities. They remain busy from dawn to dusk, supply food to men who work in the fields, fetch water, collect wood, household management and childcare responsibilities (Ranjha, Ali \& Luqman, 2009). As agents of social and economic change, rural women are also actively involved in entrepreneurial activities inside or outside their homes and are dedicated to innovating new ways of doing business or initiating changes in the production function, exploring market opportunities for their product and, ultimately changing the culture of doing business (Singh \& Manisha, 2013). It has been observed that women play crucial roles in eradicating rural poverty and improving the well-being of their families (Jamali, 2009), yet continue to face serious challenges as a result of genderbased stereotypes and discrimination that deny them equitable access to opportunities, resources, assets and services (UN - Women Watch, 2015).

Various studies show that lack of access to finance is the major barrier that women entrepreneurs face (Jamali, 2009; Roomi et al., 2009). According to the International Labor Organization (ILO, 2003), in Pakistan, rural women entrepreneurs typically have less access to formal credit and, due to unavailability of capital, they do not have funds to grow their businesses. Halkias (2011) and Itani et al. (2011) explored, that the majority of these women own a micro and small enterprise and rely on family funding or personal savings, but confront several issues that further exacerbate the barriers between them and their successful entrepreneurial ventures. These constraints may come from their own personality, immediate family or societal expectations of the people around them. They cannot get facilities because of the restrictions placed on them by society which does not allow them to receive formal training and to enter the market place. These women not only lack the financial resources but also lack awareness of the facilities available to develop their skills. However, economic necessity is forcing more and more women to engage in some sort of employment, without relieving them of their traditional roles. There is potential for Pakistani women in rural areas to develop the handicrafts sector and create income generation measures for these women, as they possess the talent and aptitude for entrepreneurial development (Pakistan Woman, 2014).

The focus of the present study is to examine the role of Sarhad Rural Support Program (SRSP) in empowering rural women entrepreneurs through microcredit in Khyber Pakhtunkhwa province of Pakistan. The province is located in the northwestern region of the country and shares an international 
border with Afghanistan. It is the third largest province of Pakistan having a geographical size of about 74,521 sq. km and a population of over 22.2 million. It is home to diverse ethnic groups, languages and cultures, and is famous for its Islamic followings (GoKP, 2014-2018). The following section presents a brief introduction to the SRSP and its strategies towards successful interventions for women's entrepreneurship development in Khyber Pakhtunkhwa.

\section{Sarhad Rural Support Program (SRSP)}

SRSP is one of the well-known non-government organizations working to alleviate poverty and promote sustainable means of livelihoods in Khyber Pakhtunkhwa province of Pakistan. It's an intermediary organization which is based on the rural support program approach to community empowerment and socioeconomic development. It was established in 1989 by the members of civil society, members of the government in their individual capacities, and members of the academia, media and training institutions (SRSP, 2013). SRSP specializes in social mobilization, gender and development, community infrastructure, education, microfinance, micro-enterprise development, governance, conflict resolution, humanitarian assistance and human resource development. Currently, it operates in the rural regions of 16 districts of the province by reaching 6,000 community organizations in which one third of these are women organizations. In recent years, because of its vast outreach in the communities, SRSP has played a prominent role in natural disasters that have hit the province and, as a result humanitarian work along with development, has become a core competency of the organization (SRSP, 2014).

With a bulging population of 22.2 million, the province of Khyber Pakhtunkhwa has low socioeconomic indicators compared to national averages. According to the 2001/02 HIES estimates, around $41 \%$ population of the province is living below the poverty line. The poverty rate amongst women is also reportedly higher as compared to other provinces (GoKP, 2010-2017). About $80 \%$ of the population resides in rural areas and is blessed with hard working and enterprising people (GoKP, 2014-2018). SRSP is therefore providing financial assistance to the deprived rural communities in the form of microcredit. The financial services programs aims to contribute to the organizational mission of reducing poverty by reaching the most marginalized; and uses a combination of traditional microfinance, microinvestment funds and innovative products and diverse models of delivery which not only address the diverse requirements in the province but are also empowering for the community. Women have been the major beneficiaries of these programs. 


\section{Core Strategies of the SRSP}

\section{Strategy to Empower Rural Women}

SRSP follows a variety of strategies to promote micro and small enterprises run by the women in rural Khyber Pakhtunkhwa. The women's disproportionate representation amongst the poorest, discrimination against them in formal sectors, and their vulnerability builds a strong case for SRSP's microfinance section to target the rural women in the province. The SRSP strategy of targeting women is based on a common belief that women, in comparison to men, have a tendency to invest their loan productively. Access to small loans, in the view of SRSP, has multiple objectives of satisfying practical gender needs; access to material assets and strategic gender needs; overcoming the prevailing patriarchal system and demanding a share of family resources. In addition, targeting women seemed to be influenced by the convergence of three distinct and inter-related paradigms of microfinance; poverty alleviation, financial selfsustainability and empowerment paradigms, assuming that access to income generating activities leads to social and economic empowerment of women.

\section{Village Banks (VBs) Model}

Based on "three-tier social mobilization strategy" opportunities to make financial services easily accessible to deprived women is created through the formation of predominately women organizations and encouraging their subsequent federation into VBs. The SRSP's VBs model has received wider recognition due to multiple reasons; empowering women to take a lead on managing these banks, offering interest-free loans, identifying deserving clients, low cost operations, generation of employment opportunities at local level and sustainable operations. Credits are granted in the light of a Poverty Score Card (PSC) to identify eligible women on the basis of their socioeconomic characteristics. However, the credit management lies with the communities and aims at building their capacity as a group. This capacity building process involves electing their own leaders, selecting their own members, creating their own bylaws, doing their own bookkeeping, funds management (disbursement and deposits), resolving loan delinquency problems, and levying their own fines on members who come late, miss meetings, or fall behind in their payments. As a capacity building organization, SRSP provides technical and back stopping support to the communities, as and when required.

\section{Strategy to Develop Enterprise}

This strategy is the most prominent as it is a "demand driven value chain approach". This approach identifies constraints and opportunities along 
a value chain for different products and addresses them through capacity building, training, linkages and networking etc. The Vocational Training Programs (VTP) for potential and existing women entrepreneurs also plays an important part in different enterprise trainings and offers training according to their needs. Similarly, the microcredit programs make an important contribution to enterprise development by providing access to capital to the women entrepreneurs. SRSP also works with the agri-business fund to build enterprise groups and train them. The enterprise interventions of SRSP make an extra effort to be inclusive for marginalized groups like women.

\section{METHODOLOGY AND DATA}

\section{Purpose of the study}

In rural areas of Khyber Pakhtunkhwa province, most of the women own small, traditional and home-based businesses. Women still prefer to engage in activities that require little mobility and minimal interaction with men. The culture allows them to generate income through applying existing skills because in Khyber Pakhtunkhwa the culture is strongly influenced by religious belief, particularly when it comes to honor, as a woman is considered to be the center of honor for the people. Driven by local customs, women are vulnerable to social and economic poverty in the province. A recent survey conducted by Shinwari (2008) reveals that the majority of Pashtun people believe that women should be allowed to get an education and access to better healthcare, but they are against the idea of women working or increasing their power. This research therefore intends to empirically investigate the role of SRSP in empowering women entrepreneurs through microcredit in rural areas of Khyber Pakhtunkhwa (Figure 1). The findings of the study are expected to create awareness regarding the potential of women entrepreneurs, who are traditionally handicapped in the matter of organizing and running their businesses, and would be helpful for researchers, policy makers, governmental and non-governmental organization who wants to work for the empowerment of women entrepreneurs. The identification of factors that influence the level of women's socioeconomic empowerment would help them to use these factors when formulating policies, in order to promote women's socioeconomic participation in entrepreneurial activities For this purpose, the present study aims:

1) To explore the entrepreneurial activities of the women in the study area.

2) To analyze the impact of SRSP's microcredit on social and economic empowerment of the women entrepreneurs in the study area. 


\section{Hypothesis}

$\mathbf{H}_{0}$ : There is no significant improvement in the social and economic empowerment index of women entrepreneurs after joining the microcredit program.

$\mathbf{H}_{\mathbf{1}}$ : There is a significant improvement in the social and economic empowerment index of women entrepreneurs after joining the microcredit program.

The present study examined the SRSP's Livelihood Strengthening Program funded by the Australian Agency for International Development (AusAidLSP). The program was started in 2011 and completed in 2014 with the aim to reduce poverty through reviving livelihoods and empowering deprived rural communities in the three districts i.e., Peshawar, Nowshera and Charsadda of Khyber Pakhtunkhwa province. Under this program, SRSP established 40 Village Banks (VBs) in which 14 VBs were established in the Peshawar, 16 in the Nowshera and 10 in the Charsadda. These VBs covered over 34,500 potential and existing women entrepreneurs in 72 villages by providing them microcredit along with technical and vocational trainings. The amount of microcredit offered was from Rs.10,000 to Rs.25,000 while the repayment period was from six to twelve months according to the loan amount, and terms and conditions. In order to encourage the rural women, the credit was offered on an interest-free basis and without collateral requirements.

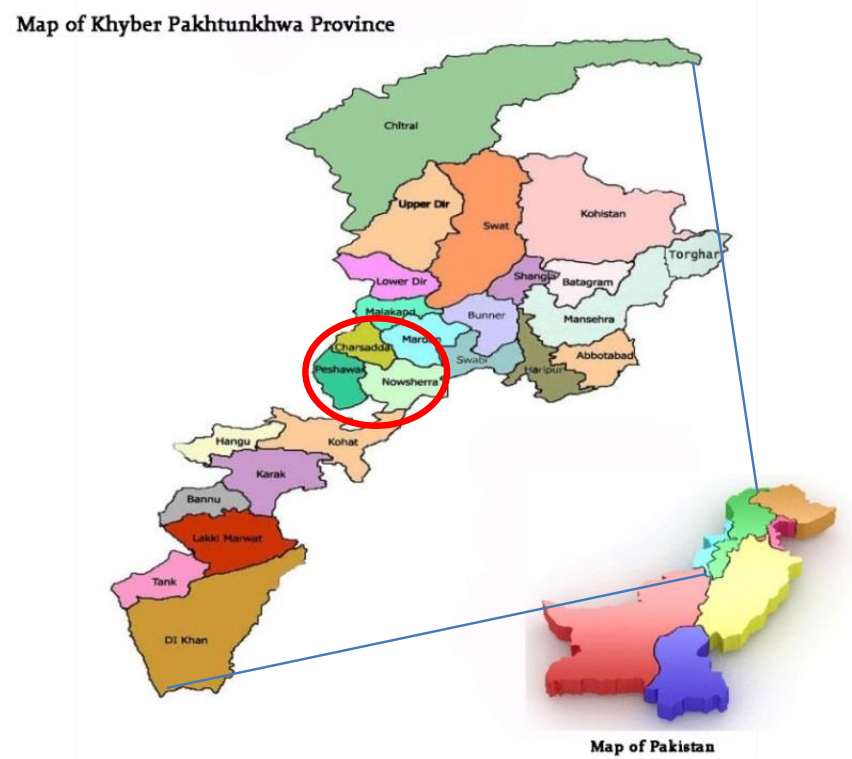

Figure 1. Map showing districts of Khyber Pakhtunkhwa Province of Pakistan 
Multistage approaches were adopted for selecting villages and sample respondents. A thorough discussion on the assessment exercise, between core management and AuSAID-LSP Support Unit, was conducted before the field experience. Based on discussions and interviews, lists of women beneficiaries of AusAID-LSP were obtained from the VBs located in the study area. From the lists, only six villages were selected purposively, two villages from each district because of the time and human constraints of the researchers. In these six villages, a total 1,374 women benefited from the microcredit of AusAID-LSP. From the population of 1,374 women, a sample size of 300 was selected by using the formula: $n=N / 1+N^{2}$, where $e=0.05$. The sample size then proportionally divided in all the six selected villages. By using a random sampling technique the sample size in each village was settled at 50. Finally, a survey was conducted in the selected villages and the targeted women were interviewed using structured questionnaires.

There are a number of scholars e.g. Manimekalai and Rajeswari (2000), Kumar, Narendra and Amar (2008) and Subashini (2013) who have drawn five dimensions of women's empowerment i.e. social, economic, cultural, legal, political and psychological. In this study, women's empowerment was measured by their social and economic levels during pre and post microcredit period. Because social and economic empowerment is considered to be the most important dimensions which are most effective in fostering women entrepreneurship. Social empowerment includes absence of discrimination against women, control over their own bodies, greater visibility in social spaces and shifts in cultural norms that place women subservient to men. Social empowerment is essential to not only giving women control over their own bodies, but also providing them with education opportunities to better their lives. On the other hand, economic empowerment includes having control over income and family resources, ownership of assets, opportunity for employment and access to markets and representation in economic decision-making roles. With economic empowerment, women can gain financial independence, enter the workforce, and have equal opportunity to gain positions of economic power. Therefore, the targeted women/ respondents of this study were asked to rate the variables under social and economic empowerment levels on a five point scale during their pre and post microcredit period. The variables are presented below in Table 1: 
Table1. Social and economic indicators and scoring

\begin{tabular}{|c|c|c|c|c|c|c|c|c|}
\hline \multirow[t]{2}{*}{ No. } & \multirow[t]{2}{*}{ Social Indicators } & \multirow{2}{*}{$\begin{array}{l}\text { Economic } \\
\text { Indicators }\end{array}$} & \multicolumn{5}{|l|}{ Score } & \multirow{2}{*}{$\begin{array}{l}\text { Max. } \\
\text { Score }\end{array}$} \\
\hline & & & 1 & 2 & 3 & 4 & 5 & \\
\hline 1. & $\begin{array}{l}\text { Recognition by } \\
\text { family members }\end{array}$ & $\begin{array}{l}\text { Material } \\
\text { Possession }\end{array}$ & $\begin{array}{l}\text { Not } \\
\text { at all }\end{array}$ & $\begin{array}{l}\text { Very } \\
\text { little }\end{array}$ & Somewhat & $\begin{array}{l}\text { Much } \\
\text { more }\end{array}$ & $\begin{array}{l}\text { To a great } \\
\text { extent }\end{array}$ & 5 \\
\hline 2. & $\begin{array}{l}\text { Recognition by } \\
\text { the society }\end{array}$ & Investment & $\begin{array}{l}\text { Not } \\
\text { at all }\end{array}$ & $\begin{array}{l}\text { Very } \\
\text { little }\end{array}$ & Somewhat & $\begin{array}{l}\text { Much } \\
\text { more }\end{array}$ & $\begin{array}{l}\text { To a great } \\
\text { extent }\end{array}$ & 5 \\
\hline 3. & $\begin{array}{l}\text { Skills } \\
\text { Development }\end{array}$ & Income & $\begin{array}{l}\text { Not } \\
\text { at all }\end{array}$ & $\begin{array}{l}\text { Very } \\
\text { little }\end{array}$ & Somewhat & $\begin{array}{l}\text { Much } \\
\text { more }\end{array}$ & $\begin{array}{l}\text { To a great } \\
\text { extent }\end{array}$ & 5 \\
\hline \multirow[t]{2}{*}{4.} & Self-Confidence & Savings & $\begin{array}{l}\text { Not } \\
\text { at all }\end{array}$ & $\begin{array}{l}\text { Very } \\
\text { little }\end{array}$ & Somewhat & $\begin{array}{l}\text { Much } \\
\text { more }\end{array}$ & $\begin{array}{l}\text { To a great } \\
\text { extent }\end{array}$ & 5 \\
\hline & Total Score & & & & & & & 20 \\
\hline
\end{tabular}

In order to assess the social and economic empowerment of rural women entrepreneurs the following indexes were developed:

\section{Social Empowerment Index (SEI)}

$$
\begin{gathered}
\text { SEI }=\frac{\sum \text { Sifj }}{\sum f j} \\
\text { SEI }=\frac{\mathrm{S} 1 \mathrm{f} 1+\mathrm{S} 2 \mathrm{f} 2+\cdots+\mathrm{Sifj}}{\mathrm{f} 1+\mathrm{f} 2+\cdots+\mathrm{fj}}
\end{gathered}
$$

Where: $S_{i}=1,2,3,4,5$ assigned score for each variable of social empowerment and; $f_{\mathrm{j}}=1,2,3,4,5$ corresponding frequency of assigned scores.

\section{Economic Empowerment Index (EEI)}

$$
\begin{gathered}
\text { EEI }=\frac{\sum \text { Sifj }}{\sum f j} \\
E E I=\frac{S 1 f 1+S 2 f 2+\cdots+S i f j}{f 1+f 2+\cdots+f j}
\end{gathered}
$$

Where: $\mathrm{Si}=1,2,3,4,5$ assigned score for each variable of economic empowerment and; $f_{\mathrm{j}}=1,2,3,4,5$ corresponding frequency of assigned scores. 
Combined Socioeconomic Empowerment Index (SEEI)

$$
\mathrm{SEEI}=\mathrm{w} 1+\mathrm{w} 2
$$

Where:

$\mathrm{w} 1=\mathrm{SEI} /(\mathrm{SEI}+\mathrm{EEI})$

$w 2=1-w 1$

and

SEI = Social Empowerment Index

$\mathrm{EEI}=$ Economic Empowerment Index

The collected data was analyzed through Statistical Package for Social Sciences (SPSS) and Microsoft-Excel programs for compilation and calculation of descriptive statistics. In addition to the central measurements and dispersion, paired t-test was used for the comparison of social and economic empowerment of the women entrepreneurs during pre and post microcredit period by using the following formula:

$$
t=\frac{\bar{d}-\mu d}{\frac{s_{d}}{\sqrt{n}}}
$$

Where:

$\bar{d}=\frac{\sum d i}{n}$

$d i=x_{1}-x_{2}$

$\mu d=\bar{x}_{1}-\bar{x}_{2}$

While:

$\bar{x}_{1}=$ after credit, $\bar{x}_{2}=$ before credit

$n_{1}=$ after credit, $n_{2}=$ before credit

$s_{d}=\sum \frac{(d-\bar{d})^{2}}{n-1} \quad$ standard deviation

\section{RESULTS AND DISCUSSION}

\section{Demographic information of sample respondents}

In this research, demographic information of the rural women entrepreneurs is important for the determination of their role in supporting their families. The following Table 2 shows demographic information of the study respondents: 
Table 2. Demographic information of sample respondents

\begin{tabular}{|c|c|c|c|c|}
\hline No. & Characteristic & Description & $\begin{array}{l}\text { Resp } \\
\text { Freq }\end{array}$ & \\
\hline 1. & Age Group (years) & $\begin{array}{l}15-30 \\
31-45 \\
46-50 \\
51-a b o v e\end{array}$ & $\begin{array}{l}55 \\
141 \\
71 \\
33\end{array}$ & $\begin{array}{l}18 \\
47 \\
24 \\
11\end{array}$ \\
\hline 2. & Literacy status & $\begin{array}{l}\text { Literate } \\
\text { Illiterate }\end{array}$ & $\begin{array}{l}112 \\
188\end{array}$ & $\begin{array}{l}37 \\
63\end{array}$ \\
\hline 3. & Marital Status & $\begin{array}{l}\text { Married } \\
\text { Unmarried }\end{array}$ & $\begin{array}{l}268 \\
32\end{array}$ & $\begin{array}{l}89 \\
11\end{array}$ \\
\hline 4. & $\begin{array}{l}\text { Household Size } \\
\text { Group }\end{array}$ & $\begin{array}{l}1-4 \\
5-9 \\
10 \text {-above }\end{array}$ & $\begin{array}{l}84 \\
166 \\
50\end{array}$ & $\begin{array}{l}28 \\
55 \\
17\end{array}$ \\
\hline
\end{tabular}

Source: Survey Data, 2014

Age is one of the main factors determining entrepreneurial processes to undertake a healthy business activity. Adult people are believed to be more mature and activity oriented. It can be seen in Table-2 that the majority (47\%) of the respondents was from the age group of 31-45 years which indicates that women from this age group were actively involved in entrepreneurial activities in the study area. After age, education plays a very important role for strengthening a sustainable business activity because it is a process by which people intentionally transmits their accumulated knowledge, skills and values from one generation to another. So, the respondents were divided into two groups i.e. literate and illiterate. It is indicated in Table-2 that only $37 \%$ of the respondents were literate up to different levels of education i.e. primary, middle and high.

It is well understood that married people have more responsibilities than the unmarried in terms of supporting their families. Marital status reflects the dependency of other family members on an individual. In the context of Khyber Pakhtunkhwa province, the people in rural areas prefer married life and are used to living in a joint family system which adheres to their local culture and traditions. From Table 2, it is quite clear that the majority $(89 \%)$ of respondents were married and had family group sizes of between 5-9 family members, which are considered to be large household sizes. This shows that the respondents were more responsible for their dependent household members. The respondents also indicated that working capital is very important for their businesses; credit to fulfill their needs; insurance to reduce vulnerability; and a safe place to deposit savings. Therefore, the 
respondents availed microcredit from the SRSP VBs because they were in need of financial assistance on their door step, to promote their business as well as to support their families.

\section{Information regarding microcredit}

Women entrepreneurs are those who use their knowledge and resources to develop business opportunities and are actively involved in managing their businesses. At the micro level, women entrepreneurs usually seek access to credit to sustain their business. The following Table 3 describes the purpose, utilization and relevant information of credit by the respondents:

Table 3. Information regarding the credit

\begin{tabular}{|c|c|c|c|c|}
\hline No. & Characteristics & Description & $\begin{array}{l}\text { Resp } \\
\text { Freq }\end{array}$ & centage \\
\hline 1. & Size of Credit (Pak Rs.) & $\begin{array}{l}10,000 \\
15,000 \\
20,000 \\
25,000\end{array}$ & $\begin{array}{l}9 \\
27 \\
95 \\
165\end{array}$ & $\begin{array}{l}3 \\
9 \\
32 \\
56\end{array}$ \\
\hline 2. & Purpose of Credit & $\begin{array}{l}\text { Embroidery } \\
\text { Handicrafts } \\
\text { Tailoring }\end{array}$ & $\begin{array}{l}103 \\
62 \\
135\end{array}$ & $\begin{array}{l}34 \\
21 \\
45\end{array}$ \\
\hline 3. & Utilization of Credit & $\begin{array}{l}\text { In the same business } \\
\text { In a new business } \\
\text { Others }\end{array}$ & $\begin{array}{l}214 \\
64 \\
22\end{array}$ & $\begin{array}{l}72 \\
21 \\
7\end{array}$ \\
\hline 4. & $\begin{array}{l}\text { People Involved in the } \\
\text { business }\end{array}$ & $\begin{array}{l}\text { Household members } \\
\text { Relatives } \\
\text { Neighbors }\end{array}$ & $\begin{array}{l}225 \\
16 \\
59\end{array}$ & $\begin{array}{l}75 \\
5 \\
20\end{array}$ \\
\hline
\end{tabular}

Source: Survey Data, 2014

Table 3 shows that the majority (56\%) of the women entrepreneurs obtained the highest amount of credit which was Rs.25,000, which clearly indicates the need and demand of high financial assistance for their entrepreneurial activities. In order to raise the economic status of rural women, proper utilization of credit in entrepreneurial activities is also very necessary. Table-3 elaborates the distribution of the respondents on the basis of utilization of microcredit. In the study area, most of the microentrepreneur women were found to be involved in home-based tailoring, embroidery and handicraft making activities. Therefore, most of the credit (45\%) was taken for the purpose of tailoring, $34 \%$ for embroidery and $21 \%$ for handicrafts respectively. The utilization of credit was mostly in their existing business while some respondents utilized it for new business activity. It was also found that few $(7 \%)$ respondents utilized the credit for other purposes i.e. agriculture and health. The better utilization of credit explores the educated 
behavior and mature approach of the sample respondents. In other words, the majority of the respondents used credit in a responsible way to make full use of it. The data in Table-3 further indicates that involving other people in a business activity was also common in the study area. As most popular homebased business activity in the research area was tailoring and embroidery, the majority (75\%) of the respondents explored run their business activity by involving a household member e.g. sisters, daughter, mother etc. Working jointly not only reduces work load but also increases the efficiency of work. However, most of the work was done at home which also reduces the cost of business activity.

\section{Assessment of social empowerment of women entrepreneurs}

Social empowerment index for the targeted women entrepreneurs is calculated from the data of the situations before and after joining the SRSP's microcredit program. The statistical results in Table 4 illustrate that the average social empowerment index increased from 8.32 to 10.12 after availing the microcredit.

Table 4. Social Empowerment Index (SEI)

\begin{tabular}{llllllll}
\hline Impact & $\mathbf{N}$ & Range & Min. & Max. & Mean & $\begin{array}{l}\text { Std. } \\
\text { Deviation }\end{array}$ & $\begin{array}{l}\text { Std. } \\
\text { Error }\end{array}$ \\
\hline $\begin{array}{l}\text { Before } \\
\text { Microcredit }\end{array}$ & 300 & 4 & 1 & 5 & 8.32 & 4.25 & 0.246 \\
$\begin{array}{l}\text { After } \\
\text { Microcredit }\end{array}$ & 300 & 4 & 1 & 5 & 10.12 & 4.92 & 0.285 \\
\hline
\end{tabular}

However, the paired t-test results in each dimension of social empowerment of women entrepreneurs are presented in Table 5.

Table 5 reveals that the four dimensions of social empowerment of women entrepreneurs i.e. recognition by family members, recognition by the society, skills development, self-confidence have been improved significantly after getting the microcredit facility. Since the t-value is found significant at $\alpha=0.01$, we can conclude that the SRSPs microcredit was effective in social empowerment of women entrepreneurs in the study area. Hence, this study accepts $\mathrm{H}_{1}$ and rejects $\mathrm{H}_{0}$. 
Table 5. Paired samples result of social empowerment

\begin{tabular}{|c|c|c|c|c|c|c|c|c|c|}
\hline \multirow{3}{*}{ Pair } & \multirow{3}{*}{$\begin{array}{l}\text { Variables of Social } \\
\text { Empowerment }\end{array}$} & \multicolumn{5}{|c|}{ Paired Differences } & \multirow{3}{*}{ t } & \multirow[b]{3}{*}{ df } & \multirow{3}{*}{$\begin{array}{l}\text { Sig. } \\
\text { (2-tailed) }\end{array}$} \\
\hline & & \multirow[b]{2}{*}{ Mean } & \multirow{2}{*}{$\begin{array}{l}\text { Std. } \\
\text { Devia- } \\
\text { tion }\end{array}$} & \multirow{2}{*}{$\begin{array}{l}\text { Std. } \\
\text { Error } \\
\text { Mean }\end{array}$} & \multicolumn{2}{|c|}{$\begin{array}{l}95 \% \text { Confidence } \\
\text { Interval of the } \\
\text { Difference } \\
\end{array}$} & & & \\
\hline & & & & & Lower & Upper & & & \\
\hline Pair 1 & $\begin{array}{l}\text { Recognition by the Fa- } \\
\text { mily } \\
\text { After Microcredit - Be- } \\
\text { fore Microcredit }\end{array}$ & .667 & .651 & .038 & .593 & .741 & 17.741 & 299 & $.000^{*}$ \\
\hline Pair 2 & $\begin{array}{l}\text { Recognition by the So- } \\
\text { ciety After Microcredit } \\
\text { - Before Microcredit }\end{array}$ & .370 & .484 & .028 & .315 & .425 & 13.252 & 299 & $.000^{*}$ \\
\hline Pair 3 & $\begin{array}{l}\text { Skills Development } \\
\text { After Microcredit - Be- } \\
\text { fore Microcredit }\end{array}$ & .183 & .388 & .022 & .139 & .227 & 8.193 & 299 & $.000^{*}$ \\
\hline Pair 4 & $\begin{array}{l}\text { Self-Confidence After } \\
\text { Microcredit - Before } \\
\text { Microcredit }\end{array}$ & .580 & .494 & .029 & .524 & .636 & 20.320 & 299 & $.000^{*}$ \\
\hline & Overall & 1.8 & 2.0 & 0.1 & 1.6 & 2.0 & 59.5 & 1196 & $.000 *$ \\
\hline
\end{tabular}

*Significant at 0.01 level

\section{Assessment of economic empowerment of women entrepreneurs}

Economic empowerment index for the targeted women entrepreneurs is calculated from the data of the situations before and after joining the SRSP's microcredit program. The statistical results in Table 6 illustrates that the average economic empowerment index increased from 10.09 to 11.01 after availing the microcredit.

Table 6. Economic Empowerment Index (EEI)

\begin{tabular}{llllllll}
\hline Impact & N & Range & Min. & Max. & Mean & $\begin{array}{l}\text { Std. } \\
\text { Deviation }\end{array}$ & $\begin{array}{l}\text { Std. } \\
\text { Error }\end{array}$ \\
\hline Before Microcredit & 300 & 4 & 1 & 5 & 10.09 & 3.83 & 0.22 \\
After Microcredit & 300 & 4 & 1 & 5 & 11.01 & 3.86 & 0.22 \\
\hline
\end{tabular}

However, the paired t-test results in each dimension of economic empowerment of women entrepreneurs are presented in Table 7.

Table 7 reveals that the four dimensions of economic empowerment of women entrepreneurs i.e. material possession, investment, income and savings have been improved significantly after getting the microcredit facility. Since the t-value is found significant at $\alpha=0.01$, we can conclude that the SRSPs microcredit was effective in the economic empowerment of women entrepreneurs in the study area. Hence, this study accepts $\mathrm{H}_{1}$ and rejects $\mathrm{H}_{0}$. 
Table 7. Paired samples result of economic empowerment

\begin{tabular}{|c|c|c|c|c|c|c|c|c|c|}
\hline \multirow{4}{*}{ Pair } & \multicolumn{6}{|c|}{ Paired Differences } & \multirow[b]{4}{*}{$t$} & \multirow[b]{4}{*}{ df } & \multirow{4}{*}{$\begin{array}{l}\text { Sig. } \\
\text { (2-tailed) }\end{array}$} \\
\hline & \multirow{3}{*}{$\begin{array}{l}\text { Variables of Economic } \\
\text { Empowerment }\end{array}$} & \multicolumn{3}{|c|}{ Paired Ditterences } & \multirow{2}{*}{\multicolumn{2}{|c|}{$\begin{array}{l}95 \% \text { Confidence } \\
\text { Interval of the } \\
\text { Difference }\end{array}$}} & & & \\
\hline & & \multirow[b]{2}{*}{ Mean } & \multirow{2}{*}{$\begin{array}{l}\text { Std. } \\
\text { Devia- } \\
\text { tion }\end{array}$} & \multirow{2}{*}{$\begin{array}{l}\text { Std. } \\
\text { Error } \\
\text { Mean }\end{array}$} & & & & & \\
\hline & & & & & Lower & Upper & & & \\
\hline Pair 1 & Material Possession & & & & & & & & \\
\hline & $\begin{array}{l}\text { After Microcredit - Be- } \\
\text { fore Microcredit }\end{array}$ & .167 & .373 & .022 & .124 & .209 & 7.733 & 299 & $.000 *$ \\
\hline Pair 2 & Investment After Mi- & & & & & & & & \\
\hline & $\begin{array}{l}\text { crocredit - Before Mi- } \\
\text { crocredit }\end{array}$ & .267 & .443 & .026 & .216 & .317 & 10.427 & 299 & $.000 *$ \\
\hline Pair 3 & Income After Micro- & & & & & & & & \\
\hline & $\begin{array}{l}\text { credit - Before Micro- } \\
\text { credit }\end{array}$ & .300 & .459 & .027 & .248 & .352 & 11.320 & 299 & $.000^{*}$ \\
\hline Pair 4 & Savings After Micro- & & & & & & & & \\
\hline & $\begin{array}{l}\text { credit - Before Micro- } \\
\text { credit }\end{array}$ & .150 & .358 & .021 & .109 & .191 & 7.264 & 299 & $.000^{*}$ \\
\hline & Overall & 0.9 & 1.6 & 0.1 & 0.7 & 1.07 & 36.7 & 1196 & $.000 *$ \\
\hline
\end{tabular}

*Significant at 0.01 level

Combined socioeconomic empowerment of women entrepreneurs In order to estimate the combined socioeconomic empowerment of women entrepreneurs, the mean difference of social and economic empowerment indexes are calculated and presented in Table 8 below:

Table 8. Mean difference of Social and Economic Empowerment Indexes

\begin{tabular}{llllllll}
\hline Dimensions & $\mathbf{N}$ & Range & Min. & Max. & Mean & $\begin{array}{l}\text { Std. } \\
\text { Deviation }\end{array}$ & $\begin{array}{l}\text { Std. } \\
\text { Error }\end{array}$ \\
\hline Social Empowerment & 300 & 4 & 1 & 5 & 1.8 & 2.0 & 0.1 \\
$\begin{array}{l}\text { Economic } \\
\text { Empowerment }\end{array}$ & 300 & 4 & 1 & 5 & 0.9 & 1.6 & 0.1 \\
\hline
\end{tabular}

However, the combined Socioeconomic Empowerment Index (SEEI) of the targeted women entrepreneurs is established by using the following formula:

$$
\text { SEEI }=w 1+w 2
$$

Where:

$\mathrm{w}_{1}=\mathrm{SEI} /(\mathrm{SEI}+\mathrm{EEI})$

By putting the values we get,

$w_{1}=1.8 /(1.8+0.9)=0.66$ 
While:

$w_{2}=1-w_{1}$

By putting the values we get,

$\mathrm{w}_{2}=1-0.66=0.34$

Hence:

SEEI $=0.66+0.34=1$

The result of combined socioeconomic empowerment of women entrepreneurs is positive and clearly indicates that the impact of microcredit on both dimensions (social and economic) of women's empowerment is positive. Though the value of the Economic Empowerment Index is slightly lower than the Social Empowerment Index it has a significant effect on entrepreneurial activities of the women. The women entrepreneurs in the study area had basic indigenous knowledge, skill and potential to run a home-based micro or small enterprise but due to lack of financial capital their activities were stagnant. The results indicate that, with the support of SRSP's microcredit, these women have gained positive recognition by the family and society, material possession, investment in the business, skills development, income, self-confidence and savings. In short, we can say that "a little credit can go a long way".

\section{CONCLUSION AND RECOMMENDATIONS}

In developing countries, policies for empowering rural women entrepreneurs have been based on three erroneous beliefs: 1 . micro-entrepreneurs women are unable to recognize themselves, 2 . they are too poor to save; and 3 . they need cheap credit for income-generating activities and establishing micro-enterprises. Thus, socioeconomic empowerment of women through enterprise development is a major development concern of the present time. In this study we concluded that in all the three selected districts of Khyber Pakhtunkhwa province, SRSP has uplifted the status of rural women entrepreneurs. The microcredit was effective in empowering women entrepreneurs to participate fully in social and economic life across all sectors to build stronger economies, achieve goals for development and sustainability, and improve the quality of their life, their families and the community. The establishment of SRSP Village Banks in the rural villages of Khyber Pakhtunkhwa province was the best strategy in reaching the marginalized groups which generally do not benefit from traditional microfinance. Run by the women, the Village Banks were found very effective in trust-building and mobilizing rural women in the province where remoteness and cultural sensitivity 
discourages women participation in any entrepreneurial activity. Moreover, the provision of microcredit without interest and collateral requirement had attracted large number of women in the study area. Skills development and entrepreneurial training had enhanced their confidence and improved their skills in establishing small scale businesses which they own and can manage all by themselves. In short, SRSP placed a strong emphasis on helping the poor rural women through subsidized credit and other social services as part of their poverty reduction strategy.

However, in spite of aforementioned interventions, the study did not find any strategy for market orientation of entrepreneurial products of the women entrepreneurs. Market creation for rural women entrepreneurs is very important and should be carried out by microcredit institutions beyond just providing credit services to the clients. To effectively address the genderrelated constraints and cultural sensitivity that limit equitable access of the rural women entrepreneurs to the local markets, support services are required by the SRSP to create linkages between the women entrepreneurs and local markets. This will not only facilitate the existing women entrepreneurs in strengthening their business but also motivate other rural women to create better decisions on business establishment and taking credit from the institutions. The study also recommends that it is very crucial if SRSP conduct business education and training for the women entrepreneurs. This will help both the institution and the women entrepreneurs to gather valuable information that will provide valuable insights in the strategy and the necessary input to find effective responses to optimize the loan defaulting.

\section{References}

Anwar, M. U., \& Amber, G. R. (2012). Female Entrepreneurs - A Review of the Literature and Proposed Conceptual Framework. Proceedings of 2nd International Conference on Business Management. Retrieved from http://umt.edu.pk/icobm2012/pdf/2C-78P.pdf

Berenbach, S., \& Guzmàn, D. (1999). The Solidarity Group Experience Worldwide. Monograph Series No. 7. ACCION International: Washington D.C, U.S.A. Retrieved from https://centerforfinancialinclusionblog.files. wordpress.com/2011/10/the-solidarity-group-experience-worldwideenglish.pdf

Claassens, S. (1993). Co-operation Is Power? Women Economic Groups and Cooperatives in Dodoma region - Tanzania. Third World Centre: University of Nijmegen. SAID/G/EG/MD, Management Systems International, Washington, D.C.

Dzisi, S. (2008). Women Entrepreneurs in Small and Medium Enterprises (SMEs) in Ghana. Doctoral Thesis. Australian Graduate School of 
Entrepreneurship, Faculty of Business and Enterprise. Swinburne University of Technology Victoria: Australia.

Farr-Wharton, R., \& Brunetto, Y. (2009). Female entrepreneurs as managers - The role of social capital in facilitating a learning culture. Gender in Management: An International Journal, 24(1), 14-31.

GoKP - Government of Khyber Pakhtunkhwa (2010-2017). Khyber Pakhtunkhwa Comprehensive Development Strategy. Planning and Development Department, Civil Secretariat Peshawar - Pakistan. Retrieved from http://lgkp.gov.pk/wp-content/uploads/2014/03/11.Report-on-Khyber-Pakhtunkhwa-Comprehensive-DevelopmentStrategy-2010-2017.pdf

GoKP - Government of Khyber Pakhtunkhwa (2014-2018). Integrated Development Strategy (IDS). Retrieved from http://www. khyberpakhtunkhwa.gov.pk/cms/downloads/kp.gov.pk-downlaods-\%20 4d03341e2270bac774adeed45144043c.pdf

Golla, M. A., Malhotra, A., Nanda, P., \& Mehra, R. (2011). Understanding and Measuring Women's Economic Empowerment. International Center for Research on Women (ICRW). Retrieved from http://www.icrw. org/files/publications/Understanding-measuring-womens-economicempowerment.pdf

Halkias, D., Nwajiuba, C., Harkiolakis, N., \& Caracatsanis, S. M. (2011). Challenges facing women entrepreneurs in Nigeria. Management Research Review, 34(2), 221-235.

IFAD - International Fund for Agricultural Development (2014). Enabling poor rural people to overcome poverty in Pakistan. Retrieved from http:// www.ifad.org/operations/projects/regions/pi/factsheets/pk.pdf

ILO - International Labor Organization (2003) Women Entrepreneurs in Pakistan: How to Improve their Bargaining Power. Retrieved from http:// www.tameer.org.pk/images/Women\%20Entrepreneurs\%20in\%20 Pakistan.pdf

Itani, H., Sidani, Y. M., \& Baalbaki, I. (2011). United Arab Emirates female entrepreneurs: motivations and frustrations. Equality Diversity and Inclusion: An International Journal, 30(5), 409-424.

Jamali, D. (2009). Constraints and opportunities facing women entrepreneurs in developing countries: A relational perspective. Gender in Management: An International Journal, 24(4), 232-251.

Kabeer, N. (1999). Resources, agency, achievements: Reflections on the measurement of women's empowerment. Development and Change, $30(3), 435-464$.

Khandker, M. (1998). Fighting Poverty with Micro credit. Oxford University Press: U.K.

Kumar, M., Narendra, S. B., \& Amar, J. (2010). Micro-finance as an antipoverty vaccine for rural India. International Review of Business and Finance, 2(1), 29-35. 
Lemire, B., Pearson, R., \& Campbell, G. G. (2001). Women and Credit: Researching the Past, Refiguring the Future. Bloomsbury Academic, 1st edition (Vol. 24). Berg.

Manimekalai, N., \& Rajeswari, G. (2000). Empowerment of women through Self Help Group (SHG). Margin, 32(4), 74-87.

Mayoux, L. C. (2005). Women's Empowerment through Sustainable Microfinance: Rethinking "Best Practice". Retrieved from http://www. chs.ubc.ca/archives/files/Women's\%20Empowerment\%20Through\%20 Sustainable\%20Micro-Finance\%20Rethinking\%20Best\%20Practice.pdf Mehnaz, S. (2013). Are Pakistan's Women Entrepreneurs Being Served by the Microfinance Sector? South Asia Finance and Private Sector. The World Bank Group. Retrieved from http://www.worldbank.org/content/dam/ Worldbank/document/Gender/Mehnaz\%20Safavian.pdf

Mishra. G. and Kiran U. V. (2014). Rural women entrepreneurs: Concerns \& importance. International Journal of Science and Research (IJSR), 3(9).

Mordi, C., Simpson, R., Singh, S., \& Okafor, C. (2010). The Role of cultural values in understanding the challenges faced by female entrepreneurs in Nigeria. Gender in Management: An International Journal, 25(1), 5-21. Mosley, P. (2001). Microfinance and Poverty in Bolivia. Journal of Development Studies, 37(4), 101- 132.

Pakistan Woman (2014). PakistanWoman.Org. Retrieved from http:// pakistanwoman.org/pakistani_women_in_rural_areas.html

PES - Pakistan Economic Survey (2013-14). Ministry of Finance. Retrieved from http://finance.gov.pk/survey/chapters_14/12_Population.pdf

Ranjha, H. M., Ali, S., \& Luqman, M. (2009). Role of women in agricultural development (pp. 198-200). In: A. Shoukat Ali \& R. Rafique (Eds.), Pak. Agri. Outlook, Multan Kitab Ghar, Multan: Pakistan.

Roomi, M. A., Harrison, P., \& Beaumont-Kerridge. J. (2009). Womenowned small and medium enterprises in England: Analysis of factors influencing the growth process. Journal of Small Business and Enterprise Development, 16(2), 270-288.

Shinwari, N. A. (2008). Understanding FATA, Community Appraisal and Motivation Program, Peshawar.

Singh, A., \& Manisha, R. (2013). Women entrepreneurs in micro, small and medium enterprises. International Journal of Management and Social Sciences Research (IJMSSR), 2(8).

Subhashini, R. (2013). Impact of institutional finance on women empowerment: An empirical analysis. Sona Global Management Review, $7(2)$.

UN - Women Watch (2015). The UN System: Working Together to Empower Rural Women. Retrieved from http://www.un.org/womenwatch/ feature/ruralwomen/

World Population Prospects (2015). The 2015 Revision, Key Findings and Advance Tables, Department of Economic and Social Affairs, Population 
Division, United Nations, New York. Retrieved from http://esa.un.org/ unpd/wpp/Publications/Files/Key_Findings_WPP_2015.pdf

\begin{abstract}
Polish)
Mikrokredyt jest uważany za skuteczne narzędzie wspierania przedsiębiorczości wśród kobiet wiejskich. Tradycyjnie, pakistańskie kobiety byłyby niechętne do uruchomienia nowej działalności gospodarczej z powodu braku kapitału i strachu przed porażkq. Wspólnie z agencjami państwowymi i prywatnymi firmami wprowadzajqcymi programy kredytowe dla kobiet o niskich dochodach i przy niskich stopach procentowych, wiele pakistańskich kobiet zakłada obecnie nowe firmy. Niniejszy artykuł ma na celu zbadanie roli Programu Wsparcia Obszarów Wiejskich (SRSP) we wzmocnieniu pozycji kobiet-przedsiębiorców poprzez mikrokredyty w prowincji Khyber Pakhtunkhwa w Pakistanie. Badanie zostało przeprowadzone w sześciu wsiach z trzech wybranych regionów w celu zbadania wpływu mikrokredytów na wzmocnienie pozycji społecznej i ekonomicznej z obszarów wiejskich kobiet-przedsiębiorców. Dane zebrano poprzez zastosowanie techniki wielostopniowego doboru z próby liczącej 300 kobiet-przedsiębiorców. Zostały opracowane indeksy społecznego i ekonomicznego upodmiotowienia dla oceny społeczno-gospodarczego upodmiotowienia kobiet. Badania wykazały znaczna poprawę statusu społecznego i gospodarczego kobiet przedsiębiorców. Ogólny efekt mikrokredytów SRSP był dodatni we wzmocnieniu pozycji i przedsiębiorczości kobiet w badanym obszarze.
\end{abstract}

Słowa kluczowe: mikrokredyty, kobiety-przedsiębiorcy, uprawomocnienie społeczne i ekonomiczne, prowincja Khyber Pakhtunkhwa, Pakistan.

\title{
Biographical notes
}

Muhammad Ammad Khan. Is a PhD Scholar of Rural Development and Management at the College of Humanities and Development Studies, China Agricultural University, Beijing - China. He received his M. Phil in Rural Development from the University of Agriculture, Peshawar - Pakistan in 2011. He has published several research papers in the fields of Rural Development, Socioeconomic Development, Conflict and Development, Women Empowerment, Microfinance and NGOs.

Nazish Kanwal. Is a Master student of Agricultural Economics and Management at the College of Economics and Management Studies, China Agricultural University, Beijing - China. She got her first Master degree in Economics from the Frontier Women University, Peshawar - Pakistan in 2009. She has published several research papers in the field of Agricultural Economics and Management, Agri-business, Rural Finance, Women Empowerment, Trade and Marketing, and Income Policy.

Peer Ghulam Nabi. Is an International Development Policy Analyst and the Director Center for Research and Development Policy (CRDP), Jammu and 
Kashmir, India. He received his PhD in Rural Development and Management from the College of Humanities and Development Studies, China Agricultural University, Beijing - China in 2014. He has published several research papers in the fields of Conflict and Development, Disaster Management, Development Policy and NGOs.

Ashfaq Ahmad Shah. Is a PhD Scholar of Rural Development and Management at the College of Humanities and Development Studies, China Agricultural University, Beijing - China. He received his M. Phil in Rural Development from the University of Agriculture, Peshawar - Pakistan in 2012. He has published several research papers in the fields of Climate Change, Disaster Management, Agricultural Development, Microfinance and NGOs. 